\title{
THE FACTORS THAT INFLUENCE CONSUMER DECISIONS IN PURCHASING PRODUCTS IN ALFAMART MINIMARKET IN PINANG, A SUBDISTRICT OF TANGERANG
}

\author{
Muhammad Tony Nawawi ${ }^{1}$; Muhammad Safiqi Ikhaz ${ }^{2}$ \\ ${ }^{1,2}$ Management Department, Faculty of Economics, Tarumanegara University \\ Jl. Letjen S. Parman No. 1, Jakarta Barat 11440, Indonesia \\ tonynawawi@yahoo.com
}

\begin{abstract}
This study analyzes the factors that influence consumer decisions in purchasing products in Alfamart minimarket in Pinang, a subdistrict of Tangerang. The population in this study is the consumers of household products that is retailed in minimarket Alfamart. The sampling technique used is purposive random sampling and samples are taken from 200 consumers. The purpose of the study is to examine and analyze the factors that may affect consumers decisions in purchasing products on Alfamart mini market. The method of analysis is multiple regression analysis and assumptions test. The validity and reliability test is done by using the help of SPSS (Statistical Program for Society Science) versus16:00. The analysis shows that all positive significant factors affect consumers decisions in purchasing products and it is evidenced by the significance $0.000<0.05$, and the factor of location has no significance as evidenced by the significance value $0.478>0.05$ and the value of $R$ Square value 0.369 , it means that it is only $36.9 \%$ of consumer decisions are influenced by factors of locations.
\end{abstract}

Keywords: product, location, price, promotion and service, testas sumptions, multiple regression

\begin{abstract}
ABSTRAK
Penelitian ini menganalisis faktor-faktor yang mempengaruhi keputusan konsumen dalam membeli produk di minimarket Alfamart di Pinang, kecamatan Kota Tangerang. Populasi penelitian ini adalah konsumen produk rumah tangga yang dijual di minimarket Alfamart. Teknik sampling yang digunakan adalah purposive random sampling dan sampel diambil dari 200 konsumen. Tujuan dari penelitian ini adalah untuk menguji dan menganalisis faktor-faktor yang dapat mempengaruhi keputusan konsumen dalam membeli produk di minimarket Alfamart. Metode analisis adalah analisis regresi berganda dan tes asumsi. Uji validitas dan reliabilitas dilakukan dengan menggunakan bantuan SPSS (Statistical Program for Society Science) versus16:00. Analisis menunjukkan bahwa semua faktor positif yang signifikan mempengaruhi keputusan konsumen dalam pembelian produk dan hal tersebut dibuktikan dengan signifikansi 0,000 <0,05, dan faktor lokasi tidak berpengaruh sebagaimana dibuktikan dengan nilai signifikansi 0,478>0,05 dan nilai nilai $R$ Square 0,369 yang berarti bahwa hanya 36,9\% dari keputusan konsumen dipengaruhi oleh faktor lokasi.
\end{abstract}

Kata kunci: produk, lokasi, harga, promosi and servis, multiple regression 


\section{PENDAHULUAN}

Perilaku konsumen dalam membeli produk semakin kompleks sehingga dewasa ini berbelanja adalah sebuah kegiatan yang rutin. Oleh karena itu, perkembangan bidang retailing store saat ini mengalami persaingan yang semakin ketat. Pemasaran mempengaruhi hampir semua aspek kehidupan sehari-hari dan memegang peranan yang besar dalam pertumbuhan dan pembangunan ekonomi. Sistem pemasaran yang efektif adalah penting bagi masa depan bangsa.

Konsep pemasaran (marketing concept) menyatakan bahwa suatu organisasi harus memuaskan kebutuhan dan keinginan konsumen agar dapat memperoleh keuntungan. Untuk menerapkan konsep pemasaran, organisasi harus memahami dan tetap dekat dengan konsumen untuk menyajikan produk serta layanan yang akan dibeli dan digunakan oleh konsumen (Peter and Olson, 1999) dan menempatkan konsumen sebagai pusat kegiatan pemasaran. Kebutuhan dan keinginan konsumen harus dimasukkan ke dalam produk yang ditawarkan oleh perusahaan sehingga pembeli dengan sumber-sumber yang terbatas akan memaksimalkan kepuasan mereka. Bagi perusahaan, pemasaran tidak hanya sekedar menjual dan memasang iklan atau mencari keuntungan semata, tetapi lebih mengarah pada pemenuhan kebutuhan dan kepuasan konsumen.

Kemajuan peradaban manusia dan perubahan lingkungan akan membawa perubahan terhadap perilaku kehidupan manusia baik secara individual maupun sosial. Perubahan ini membawa pengaruh terhadap perilaku dan pola hidup konsumen dalam memilih barang dan tempat untuk memenuhi kebutuhan hidup. Salah satu usaha perdagangan yang dibutuhkan oleh masyarakat pada saat ini adalah usaha di bidang minimarket. Dalam bidang ini, perilaku konsumen merupakan hal yang sangat penting untuk dapat mempertahankan kelangsungan usaha karena perilaku konsumen memberikan petunjuk bagaimana memenuhi selera konsumen sehingga dapat memberikan pelayanan yang baik, harga yang terjangkau, produk berkualitas, promosi yang menarik dan lokasi yang strategis.

Kendala yang sering dihadapi oleh pihak manajemen toko dalam membuat dan menerapkan strategi pemasaran adalah informasi akurat mengenai perilaku konsumen yang sedikit, sehingga manajemen perlu mencari dan mengumpulkan informasi tentang konsumen untuk menarik dan mempertahankan konsumen. Perilaku konsumen merupakan proses keputusan dan aktivitas fisik individu yang digunakan ketika mengevaluasi, mendapatkan, menggunakan atau menentukan barang dan jasa (Loudon and Bitta, 1993). Individu adalah konsumen, secara umum merupakan seseorang yang mengidentifikasikan kebutuhan atau keinginan, membuat keputusan pembelian dan kemudian menentukan produk selama proses mengkonsumsi (Solomon, 2002).

Saat ini berbagai macam pusat perbelanjaan eceran mulai bermunculan dengan bermacam bentuk dan ukuran. Beberapa contoh bentuk pusat perbelanjaan eceran adalah minimarket dan supermarket. Minimarket dan supermarket semakin banyak ditemui di berbagai tempat, hal ini menunjukkan bahwa keberadaannya di tengah-tengah masyarakat menjadi semakin penting. Perubahan cara pandang konsumen juga mendorong pertumbuhan minimarket dan supermarket, salah satu perubahan tersebut adalah konsumen pergi berbelanja tanpa memandang produk atau merek yang spesifik tetapi hanya sekedar keinginan untuk keluar dari rumah untuk melihat-lihat dan menghabiskan waktu senggang.

AlfaMart adalah salah satu minimaket yang berada di lingkungan Kunciran Indah, sepanjang Jalan Sultan Ageng Tirtayasa, Pinang, Kota Tangerang, Provinsi Banten. Minimarket ini menyediakan berbagai macam produk kebutuhan seperti makanan minuman ringan, produk kecantikan dan perlengkapan rumah tangga. Konsumen dapat menentukan dan memilih sendiri barang yang disukai. Suasana minimarket dibuat sedemikian rupa sehingga pembeli betah berbelanja di tempat itu. Karyawan diharapkan tidak hanya sekedar melayani permintaan dan pembayaran atas barang yang 
dibeli oleh konsumen tetapi juga dituntut untuk bekerja secara terampil, bersikap ramah serta berpenampilan sopan dan rapi. Penampilan dan pelayanan yang baik dapat menjadi nilai tambah tersendiri yang diberikan konsumen kepada minimarket tersebut, sehingga konsumen mau datang kembali di kemudian hari.

Dalam melakukan pembelian, konsumen selalu memperhatikan faktor-faktor yang memotivasi mereka. Untuk memotivasi konsumen dalam melakukan pembelian, atribut-atribut yang dimiliki minimarket AlfaMart seperti produk yang bagus dan menarik, lokasi yang strategis, harga yang terjangkau, promosi yang menarik serta pelayanan yang memuaskan harus diperhatikan. Faktor-faktor tersebut mempunyai pengaruh terhadap perilaku dan keputusan konsumen dalam membeli produk.

Berdasarkan latar belakang tersebut, penelitian ini dilakukan untuk mengetahui apakah faktor produk, lokasi, harga, promosi dan harga mempunyai pengaruh yang signifikan baik secara sendirisendiri ataupun keseluruhan terhadap keputusan konsumen dalam membeli produk di Minimarket Alfamart. Tujuan Penelitian ini adalah untuk menguji secara empiris pengaruh faktor produk, lokasi, harga, promosi dan pelayanan baik secara sendiri-sendiri ataupun bersamaan terhadap keputusan konsumen dalam membeli produk di Minimarket Alfamart. Penelitian ini bermanfaat dalam memberikan masukan kepada Minimarket Alfamart dalam menentukan kebijakan pemasaran produk dengan mempertimbangan aspek lokasi, harga, promosi dan pelayanan yang memuaskan. Hasil penelitian ini diharapkan dapat menambah informasi dan pengetahuan sebagai pembanding bagi penelitian yang akan datang sehingga dapat memperbaiki segala kekurangan yang ada dalam penelitian ini dan menambah pengetahuan dan wawasan khususnya dalam hal pengambilan keputusan pembelian untuk konsumen

\section{Konsep Pemasaran}

Konsep pemasaran merupakan sebuah falsafah bisnis yang menyatakan bahwa kepuasan konsumen adalah dasar kebenaran sosial dan ekonomi kehidupan sebuah perusahaan (Stanton, Lamarto, 1996). Menurut Swastha (1996), ada tiga faktor penting yang mendasari konsep pemasaran di atas, yaitu: (1) Orientasi Konsumen; perusahaan akan mencapai kesuksesan apabila perusahan berorientasi pada konsumen, hal ini berarti bahwa perusahaan harus berusaha menciptakan produk sedemikian rupa sehingga sesuai dengan keinginan dan kebutuhan konsumen. (2) Koordinasi dan Integrasi dalam Perusahaan; untuk memberikan kepuasan konsumen secara optimal semua elemen pemasaran yang ada di dalam perusahaan harus dikoordinasikan dan diintegrasikan dengan tujuan untuk menghindari pertentangan dalam perusahaan maupun dengan pasar. (3) Mendapatkan Laba Melalui Kepuasan Konsumen; perusahaan menggunakan konsep pemasaran dengan maksud untuk memperbaiki dan menciptakan hubungan yang baik dengan konsumen. Hubungan ini akan sangat bermanfaat dalam menunjang kelangsungan usaha dan sekaligus dapat meningkatkan laba perusahaan karena dengan terpenuhinya kepuasan konsumen akan menguntungkan perusahaan.

\section{Perilaku Konsumen}

Perilaku konsumen menurut Engel, Blackwell dan Miniard, (1994) adalah tindakan yang langsung terlibat dalam mendapatkan, mengkonsumsi dan menghabiskan produk dan jasa termasuk proses keputusan yang mendahului dan menyusuli tindakan ini. Menurut Swastha (1996) perilaku konsumen adalah kegiatan-kegiatan individu yang secara langsung terlibat dalam mendapatkan dan menggunakan barang dan jasa, termasuk di dalamnya proses pengambilan keputusan pada persiapan dan penentuan kegiatan-kegiatan tersebut.

Model perilaku konsumen dapat dipahami melalui pengalaman sehari-hari pada waktu menjual barang dan jasa. Semakin besar perusahaan dan pasar maka kesempatan untuk berhubungan dengan konsumen semakin kecil, hal ini menyebabkan penelitian konsumen penting dilakukan. 
Mengetahui apa yang ada dalam pikiran seseorang sewaktu membeli produk merupakan hal yang sulit. Titik tolak dalam memahami perilaku konsumen adalah seperti model rangsangan tanggapan yang diperlihatkan dalam gambar 1 (Kotler, 2008)

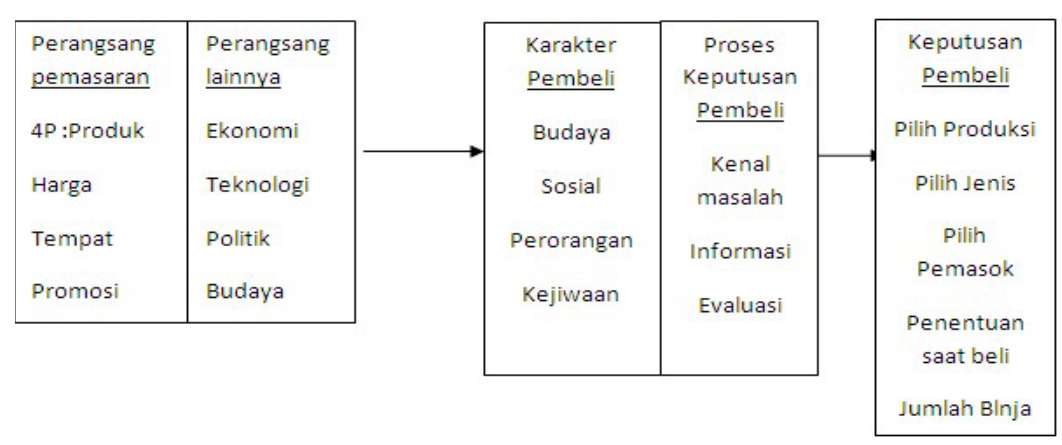

Gambar 1 Model Perilaku Konsumen

Sebelum konsumen memutuskan untuk membeli suatu produk yang diinginkan, mereka memerlukan suatu rangsangan yang dapat menimbulkan keinginan membeli produk tersebut. Melalui rangsangan-rangsangan yang ada, konsumen dapat menentukan barang yang akan dibeli. Sesuai gambar di atas, terdapat dua macam rangsangan, yaitu rangsangan pemasaran dan rangsangan lain. Kedua rangsangan tersebut terdiri dari empat tahap yaitu produk, harga, tempat/lokasi dan promosi.

Produk adalah segala sesuatu yang dapat ditawarkan ke dalam pasar untuk dapat diperhatikan, dimiliki, dipakai atau dikonsumsi sehingga dapat memuaskan keinginan dan kebutuhan (Stanton, Lamarto, 1996). Harga adalah jumlah uang yang dibutuhkan untuk mendapatkan sejumlah kombinasi dari barang beserta pelayanannya (Stanton, Lamarto, 1996). Lokasi/Tempat adalah lokasi penjualan. Penentuan lokasi yang tepat menentukan potensi laba yang diperoleh. Dalam hal ini, potensi permintaan di wilayah penjualan perlu mendapatkan perhatian, sebab untuk menganalisa tempat penjualan yang strategis, analisa potensi pasar dalam masyarakat diperlukan. Promosi adalah unsur yang didayagunakan untuk memberitahukan dan membujuk pasar tentang produk baru perusahaan (Stanton, Lamarto, 1996). Tujuan promosi adalah untuk meningkatkan penjualan dan keuntungan. Melakukan promosi secara tersendiri belum mampu meningkatkan penjualan karena perilaku konsumen dalam membeli produk dipengaruhi oleh produk, harga, jasa, pembiayaan dan aspek lain dari pemasaran. Tujuan promosi adalah meningkatkan reaksi atau mendorong tanggapan pembelian potensial terhadap produk perusahaan.

Faktor-faktor yang mempengaruhi perilaku konsumen dalam memutuskan untuk membeli suatu produk tertentu digambarkan oleh Kotler (2008) sebagai berikut: (1). Faktor budaya adalah faktor penentu keinginan dan perilaku seseorang yang paling mendasar. Budaya bersifat sangat luas dan menyangkut segala aspek kehidupan manusia, mempelajari perilaku konsumen berarti juga mempelajari perilaku manusia. (2) Faktor sosial adalah faktor yang juga mempengaruhi perilaku konsumen, seperti kelompok referensi, keluarga, serta peranan dan status sosialnya. (3). Faktor pribadi adalah faktor karakteristik pribadi yang mempengaruhi keputusan seseorang untuk membeli suatu barang atau jasa. (4). Faktor psikologis adalah motivasi, persepsi, pembelajaran, keyakinan dan sikap perilaku seseorang dalam membeli sebuah produk atau jasa.

Keputusan pembelian adalah keputusan membeli yang dilakukan oleh konsumen yang telah melalui tahap-tahap sebelumnya dengan mempertimbangkan atribut-atribut yang ditawarkan. Menurut Swastha dan Handoko (1996) keputusan pembelian adalah proses mengidentifikasi semua pilihan yang ada untuk memutuskan pilihan dengan menilai pilihan secara sistematis dan objektif beserta 
sasarannya. Ada empat jenis perilaku konsumen berdasarkan tingkat keterlibatan pembeli dan tingkat perbedaan merk (Kotler, 2002): (1). Perilaku pembelian yang rumit yaitu ketika para konsumen terlibat dalam pembelian dan sadar akan perbedaan perbedaan besar yang ada antara merek. Perilaku pembelian yang rumit itu lazim terjadi bila produk mahal, jarang dibeli, berisiko dan sangat mengekspresikan diri. Konsumen pada perilaku pembelian yang rumit pada umumnya tidak tahu banyak tentang kategori produk. (2) perilaku pembelian yang mencari variasi yaitu situasi pembelian yang ditandai oleh keterlibatan konsumen yang rendah namun perbedaan merek yang signifikan. Dalam situasi ini, konsumen sering melakukan peralihan merek. Perpindahan merek terjadi karena konsumen mencari variasi dan bukan karena ketidakpuasan. (3) Perilaku pembelian yang mengurangi ketidaknyamanan adalah ketika konsumen melalui suatu keadaan perilaku, kemudian memiliki beberapa kepercayaan yang baru dan berakhir dengan penilaian terhadap pilihan yang dirasakan tepat. (4) Perilaku pembelian yang rutin berdasarkan kebiasaan adalah produk yang dibeli dengan kondisi keterlibatan konsumen yang rendah dan tidak ada perbedaan merek yang signifikan. Jika konsumen tetap mengambil merek yang sama hal itu karena kebiasaan bukan karena kesetiaan terhadap merek yang kuat.

Proses keputusan pembelian melibatkan beberapa faktor yang mempengaruhi pembeli. Menurut Kotler (2002), ada lima peranan yang dimainkan dalam keputusan pembelian, yaitu: (1). Pencetus (initiator): seseorang yang pertama kali mengusulkan gagasan untuk membeli suatu produk atau jasa. (2). Pemberi pengaruh (influencer): seseorang yang memiliki pandangan atau saran yang dapat mempengaruhi keputusan. (3) Pengambil keputusan (decider): seseorang yang mengambil keputusan untuk setiap komponen keputusan pembelian, apakah membeli atau tidak membeli, bagaimana membeli dan di mana akan membeli. (4). Pembeli (buyer): orang yang melakukan pembelian yang sesungguhnya. (5) Pemakai (user): sesorang yang mengkonsumsi atau menggunakan produk atau jasa yang bersangkutan.

\section{Tahap-tahap dalam Proses Keputusan Pembelian}

Proses keputusan pembelian merupakan rangkaian beberapa tahap yang bisa dilalui konsumen baik seluruhnya atau sebagian. Konsumen dapat melewatkan atau membalik beberapa tahap terutama pada pembelian dengan keterlibatan yang rendah. Tahap-tahap proses keputusan pembelian adalah (Kotler, 2002) pengenalan masalah, pencarian informasi, evaluasi alternative, keputusan pembelian. Tanggapan Pembelian, meliputi pilihan produk, merek, penyalur, waktu pembelian dan jumlah pembelian.

Dalam dunia perdagangan saat ini, toko barang kebutuhan sehari-hari dengan ruangan yang tidak terlalu luas (minimarket) bukan lagi merupakan istilah asing bagi masyarakat umum, terutama yang tinggal dikota-kota besar. Pengertian minimarket adalah "Toko yang mengisi kebutuhan masyarakat akan warung yang berformat modern yang dekat dengan pemukiman penduduk sehingga dapat mengungguli toko atau warung" (Ma'ruf, 2005). Minimarket secara umum adalah suatu tempat yang menjual barang-barang yang bersifat umum seperti pakaian, perlengkapan alat-alat rumah tangga, barang pecah belah dan sebagainya yang biasanya sudah diatur dalam bagian-bagian berdasarkan kesamaan jenis (homogenity) dari barang-barang tersebut yang ukurannya lebih kecil dari supermarket.

Dalam penelitian Sambodo (2005) ternyata ditemukan hubungan yang positif dan pengaruh yang signifikan antara keputusan pembelian dengan atribut toko seperti produk, harga, lokasi, dan pelayanan. Secara parsial faktor yang paling dominan adalah produk. Penelitian Hartanti (2004) menemukan hubungan yang positif dan pengaruh yang signifikan antara keputusan pembelian dengan atribut toko seperti produk, harga dan lokasi. Secara parsial faktor yang paling dominan adalah produk. 
Kerangka teori dalam suatu penelitian berisi tentang keseluruhan kegiatan penelitian yang merupakan suatu kesatuan yang utuh yang digunakan dalam penelitian tersebut. Hal ini sangat diperlukan karena dengan membaca kerangka teori dapat diketahui dengan jelas gambaran isi penelitian secara keseluruhan. Adapun kerangka teori untuk penelitian ini adalah sebagai berikut:

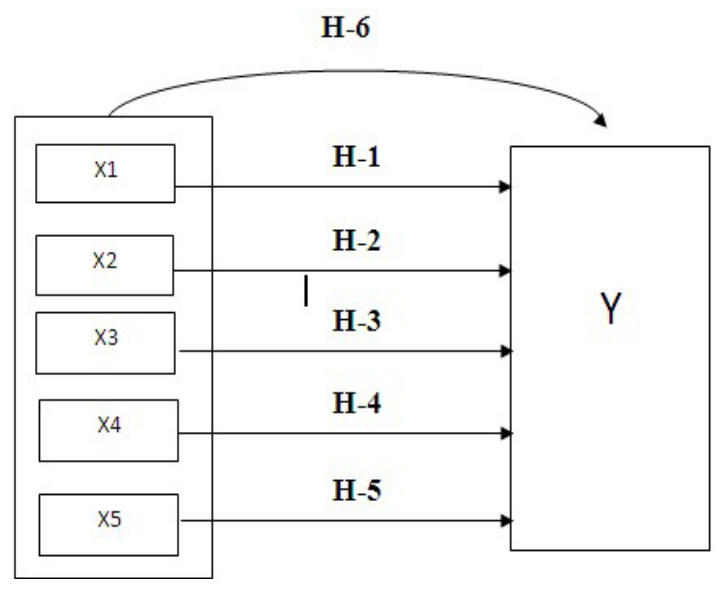

Gambar 2 Kerangka Teori

Berdasarkan kerangka teori yang telah diuraikan di atas, maka hipotesis dalam penelitian ini adalah: (1) Ada pengaruh yang signifikan antara faktor produk (X1) terhadap keputusan konsumen (Y) dalam melakukan pembelian pada Minimarket Alfamart. (2) Ada pengaruh yang signifikan antara faktor lokasi (X2) terhadap keputusan konsumen dalam melakukan pembelian (Y) pada Minimarket Alfamart. (3) Ada pengaruh yang signifikan antara faktor harga (X3) terhadap keputusan konsumen dalam melakukan pembelian (Y) pada Minimarket Alfamart. (4) Ada pengaruh yang signifikan antara faktor promosi (X4) terhadap keputusan konsumen dalam melakukan pembelian (Y) pada Minimarket Alfamart. (5) Ada pengaruh yang signifikan antara faktor pelayanan (X5) terhadap keputusan konsumen dalam melakukan pembelian (Y) pada Minimarket Alfamart. 6. Ada pengaruh yang signifikan antara faktor produk (X1), lokasi (X2), harga (X3), promosi (X4) dan pelayanan (X5) secara bersama-sama terhadap keputusan konsumen dalam melakukan pembelian (Y) pada Minimarket Alfamart.

\section{METODE}

\section{Desain Penelitian}

Penelitian ini dilakukan di beberapa lokasi Alfamart yang ada di Kunciran Pinang Kota Tangerang. Penelitian ini menggunakan desain survei yang mengambil sampel dari suatu populasi dan menggunakan kuesioner sebagai alat pengumpulan data pokok (Singarimbun, 1995). Populasi adalah jumlah dari keseluruhan objek (satuan-satuan atau individu-individu) yang berkarakteristik hendak diduga (Djarwanto dan Pangestu, 1996). Populasi dalam penelitian ini adalah seluruh konsumen yang berbelanja atau membeli di Minimarket Alfamart yang jumlahnya tidak terhingga. Sampel adalah sebagian dari populasi yang karakteristiknya hendak diselidiki, dan dianggap bisa mewakili keseluruhan populasi, jumlahnya lebih sedikit dari populasi (Djarwanto dan Pangestu, 1996). Sampel dalam penelitian ini adalah sebanyak 200 orang pembeli di minimarket Alfamart. 
Teknik pengambilan sampel untuk penelitian ini menggunakan nonprobability sampling dengan tipe accidental sampling. Accidental sampling adalah teknik penentuan sampel berdasarkan kebetulan, yaitu siapa saja yang secara kebetulan ditemui pada saat dilakukan penelitian (Sugiyono, 1997). Metode accidental sampling ini digunakan jika populasi tidak terhingga. Untuk memperoleh data, cara yang digunakan adalah dengan memberikan kuesioner kepada pengunjung minimarket Alfamart yang kebetulan melakukan pembelian pada saat dilakukan penelitian.

Definisi operasional variabel penelitian adalah sebagai berikut:

Produk(X1) : Segala sesuatu yang ditawarkan pada minimarket Alfamart. Indikator yang digunakan adalah Merek, Desain/model, Kualitas dan Kelengkapan.

Lokasi (X2) : Lokasi adalah suatu tempat yang digunakan oleh minimarket Alfamart.

Harga (X3) : Harga adalah jumlah uang yang dibutuhkan untuk mendapatkan sejumlah barang yang dijual pada Minimarket Alfamart.

Promosi (X4) : Kegiatan yang dilakukan untuk membujuk konsumen agar melakukan pembelian pada minimarket Alfamart

Pelayanan (X5) : Proses pemenuhan kebutuhan konsumen yang dilakukan oleh minimarket Alfamart. Definisi keputusan pembelian yaitu keputusan konsumen (Y) untuk melakukan pembeli pada Minimarket Alfamart.

Instrumen yang digunakan dalam penelitian ini adalah daftar kuesioner dan studi pustaka. Kuesioner ini berisi daftar pertanyaan yang digunakan untuk mengetahui faktor-faktor yang menjadi alasan utama konsumen melakukan pembelian di minimarket Alfamart. Dalam kuesioner ini pertanyaan yang dibuat diuji dengan uji validitas dan uji reliabilitas, serta jawaban dinilai dengan menggunakan skala Likert.

Data primer, yaitu data yang diperoleh melalui penelitian langsung kepada objek penelitian, untuk memperoleh data yang berhubungan dengan penelitian yang dilakukan. Data tersebut adalah jawaban responden atas kuesioner yang diberikan. Dalam hal ini yang menjadi responden pada penelitian ini adalah konsumen yang sedang atau pernah melakukan pembelian di minimarket Alfamart. Data sekunder adalah data yang berguna untuk mendukung data primer yang sebelumnya telah disusun oleh pihak lain melalui referensi penelitian terdahulu.

Metode observasi adalah cara pengumpulan data dengan melakukan pengamatan langsung terhadap keputusan konsumen untuk melakukan pembelian di minimarket Alfamart. Metode kuesioner, yaitu cara pengumpulan data dengan mengajukan pertanyaan tertentu (angket) kepada beberapa konsumen yang melakukan pembelian di minimarket Alfamart.

\section{Uji Validitas dan Reliabilitas}

Uji validitas dilakukan untuk mengetahui sejauh mana suatu sifat alat pengukur tersebut dapat digunakan untuk mengukur suatu variabel. Suatu instrumen dinyatakan valid, apabila korelasi antara dua nilai suatu butir dengan nilai totalnya minimal sebesar 0,3 (Sugiyono, 2003). 
Tabel 1 Item-Total Statistics

\begin{tabular}{cc}
\hline Variabel & Valid ( Corrected Item-Total Correlation ) \\
\hline Produk & 0,324 \\
Lokasi & 0,367 \\
Harga & 0,612 \\
Promosi & 0,485 \\
Pelayanan & 0,471 \\
Keputusan Membeli & 0,352 \\
\hline \multicolumn{2}{c}{ Sumber : Data Primer (Hasil Olahan SPSS) }
\end{tabular}

Berdasarkan data primer yang telah berhasil pengolahan datanya dengan SPSS, maka setiap butir item-total correlation variable menghasilkan bobot nilai diatas nilai 0,30 , sesuai dengan persyaratan minimal. Hal ini menunjukkan bahwa semua variable dalam penelitian ini dinyatakan valid. Uji Reliabilitas, menunjukkan rentang pengukuran itu akurat, stabil dan konsisten apabila dilakukan pengukuran kembali dengan subjek yang sama. Dalam uji reliabilitas menggunakan metode Alpha-Cronbach. (Arikunto, 2002).

Tabel 2 Reliability Statistics

\begin{tabular}{cc}
\hline Variabel & Alpha-Cronbach \\
\hline Produk ( 4 item ) & 0,713 \\
Lokasi ( 4 item ) & 0,695 \\
Harga (2 item) & 0,758 \\
Promosi (2 item) & 0,651 \\
Pelayanan ( 4 item) & 0,718 \\
Keputusan Pembelian ( 5 item) & 0,774 \\
\hline Sumber: Data Primer (Hasil Olahan SPSS)
\end{tabular}

Berdasarkan data primer yang telah berhasil diolah dengan SPSS, maka setiap butir Cronbach's Alpha variable menghasilkan bobot nilai diatas nilai 0, 60, sebagai mana persyaratan minimalnya. Hal ini menunjukkan bahwa semua variable dalam penelitian ini dinyatakan reliable, karena nilai Alpha-Cronbach melebihi nilai 0,60.

Penelitian ini menggunakan analisis deskriptif dan kuantitatif. Analisis deskriptif adalah analisis yang digunakan untuk mengetahui gambaran dan mendiskripsikan keadaan konsumen pada Minimarket Alfamart. Hal ini dapat dilihat dari pertanyaan pada kuesioner yang diisi oleh responden. Kuesioner tersebut bersifat kualitatif. Skala yang digunakan dalam analisis ini adalah skala Likert. Analisis kuantitatif adalah analisis dari faktor-faktor yang dapat diukur dengan angka-angka yang menggunakan Analisis Regresi Linear Berganda

\section{Pengujian Hipotesis}

Berikut ini hasil dari Uji t yang telah dilakukan: 
Tabel 3 Uji T

\begin{tabular}{|c|c|c|c|c|c|c|c|c|}
\hline \multicolumn{9}{|c|}{ Coefficients $^{\mathrm{a}}$} \\
\hline & \multirow[t]{2}{*}{ Model } & \multicolumn{2}{|c|}{$\begin{array}{l}\text { Unstandardized } \\
\text { Coefficients }\end{array}$} & \multirow{2}{*}{$\begin{array}{c}\begin{array}{c}\text { Standardized } \\
\text { Coefficients }\end{array} \\
\text { Beta }\end{array}$} & \multirow[t]{2}{*}{$\mathbf{t}$} & \multirow[t]{2}{*}{ Sig. } & \multicolumn{2}{|c|}{$\begin{array}{c}\text { Collinearity } \\
\text { Statistics }\end{array}$} \\
\hline & & B & Std. Error & & & & Tolerance & VIF \\
\hline \multirow[t]{6}{*}{1} & (Constant) & 1,376 &, 276 & & 4,977 &, 000 & & \\
\hline & Produk/Barang &, 143 & 069 &, 159 & 2,081 & 039 & ,557 & 1,796 \\
\hline & Lokasi/Tempat &,- 052 & 073 &,- 048 &,- 711 & ,478 &, 713 & 1,403 \\
\hline & Harga &, 105 &, 045 &, 166 & 2,315 &, 022 & 631 & 1,584 \\
\hline & Promosi &, 114 &, 050 &, 150 & 2,277 &, 024 &, 752 & 1,329 \\
\hline & Pelayanan & ,304 &, 067 &, 329 & 4,507 &, 000 & 610 & 1,640 \\
\hline
\end{tabular}

a. Dependent Variable: Keputusan Pembelian

Dari tabel di atas, dapat dirumuskan persamaan regresinya adalah sebagai berikut:

$$
Y=1,376+0,143 X_{1}-0,052 X_{2}+0,105 X_{3}+0,114 X_{4}+0,304 X_{5}+e
$$

Nilai konstanta (a) $=1,376$, artinya bahwa apabila nilai variabel independen sama dengan nol, maka nilai Y meningkat sebesar 1,376. Nilai koefisien $\mathrm{X}_{1}=0,143$, hal ini menunjukkan bahwa apabila nilai $\mathrm{X}_{1}$ meningkat 1 satuan, maka keputusan pembelian konsumen akan meningkat sebesar 0,143 satuan dengan asumsi faktor lainnya tetap. Nilai koefisien $\mathrm{X}_{2}=-0,052$, hal ini menunjukkan bahwa apabila nilai $X_{2}$ meningkat 1 satuan, maka keputusan pembelian konsumen akan menurun sebesar 0,052 satuan dengan asumsi faktor lainnya tetap. Nilai koefisien $X_{3}=0,105$, hal ini menunjukkan bahwa apabila nilai $\mathrm{X}_{3}$ meningkat 1 satuan, maka keputusan pembelian konsumen akan meningkat sebesar 0,105 satuan dengan asumsi faktor lainnya tetap. Nilai koefisien $\mathrm{X}_{4}=0,114$, hal ini menunjukkan bahwa apabila nilai $\mathrm{X}_{4}$ meningkat 1 satuan, maka keputusan pembelian konsumen akan menurun sebesar 0,114 satuan dengan asumsi faktor lainnya tetap. Nilai koefisien $\mathrm{X}_{5}=0,304$, hal ini menunjukkan bahwa apabila nilai $\mathrm{X}_{5}$ meningkat 1 satuan, maka keputusan pembelian konsumen akan meningkat sebesar 0,304 satuan dengan asumsi faktor lainnya tetap.

Penjelasan hasil uji t dari masing-masing variable untuk menjawab hipotesis dalam penelitian ini adalah sebagai berikut: (1) Berdasarkan hasil tabel di atas, nilai signifikansi dari variabel produk adalah 0,039, jika dibandingkan dengan $\alpha=0,05$ maka nilai tersebut masih di bawahnya sehingga dapat disimpulkan bahwa terdapat pengaruh yang signifikan dalam faktor produk terhadap keputusan pembelian konsumen dengan tingkat keyakinan 95 persen. (2) Berdasarkan hasil dari tabel di atas, nilai signifikansi dari variabel lokasi adalah 0,478 , jika dibandingkan dengan $\alpha=0,05$ maka nilai tersebut lebih besar (tinggi) sehingga dapat disimpulkan bahwa tidak terdapat pengaruh yang signifikan dalam faktor lokasi terhadap keputusan pembelian konsumen dengan tingkat keyakinan 95 persen. (3) Berdasarkan hasil dari tabel di atas, nilai signifikansi dari variabel harga adalah 0,022, jika dibandingkan dengan $\alpha=0,05$ maka nilai tersebut masih dibawahnya sehingga dapat disimpulkan bahwa terdapat pengaruh yang signifikan dalam faktor harga terhadap keputusan pembelian konsumen dengan tingkat keyakinan 95 persen. (4) Berdasarkan hasil dari tabel di atas, nilai signifikansi dari variabel promosi adalah 0,024, jika dibandingkan dengan $\alpha=0,05$ maka nilai tersebut masih dibawahnya sehingga dapat disimpulkan bahwa terdapat pengaruh yang signifikan dalam faktor promosi terhadap keputusan pembelian konsumen dengan tingkat keyakinan 95\%. (5) Berdasarkan hasil dari tabel di atas, bahwa nilai signifikansi dari variabel pelayanan adalah 0,000, jika dibandingkan dengan $\alpha=0,05$ maka nilai tersebut masih di bawahnya sehingga dapat disimpulkan bahwa terdapat pengaruh yang signifikan dalam faktor pelayanan terhadap keputusan pembelian konsumen dengan tingkat keyakinan 95 persen. (6) Berdasarkan hasil dari tabel di atas, nilai signifikansi dari faktor variabel produk, lokasi, harga, promosi dan pelayanan adalah 0,000, jika 
dibandingkan dengan $\alpha=0,05$ maka nilai tersebut masih dibawahnya sehingga dapat disimpulkan bahwa terdapat pengaruh yang signifikan dalam faktor-faktor tersebut terhadap keputusan pembelian konsumen dengan tingkat keyakinan 9 persen.

Tabel 4 Model Summary ${ }^{\mathrm{b}}$

\begin{tabular}{lcccc}
\hline Model & $\mathbf{R}$ & R Square & Adjusted R Square & Std. Error of the Estimate \\
\hline 1 &, $607^{\text {a }}$ &, 369 &, 353 &, 39905 \\
\hline a. Predictors: (Constant), Pelayanan, Lokasi/Tempat, Promosi, Harga, Produk/Barang \\
b. Dependent Variable: Keputusan Pembelian
\end{tabular}

Dari tabel di atas dapat dijelaskan bahwa nilai koefisien regresi (R) sebesar 0,607, Untuk mengetahui besarnya pengaruh faktor produk $\left(\mathrm{X}_{1}\right)$, lokasi $\left(\mathrm{X}_{2}\right)$, harga $\left(\mathrm{X}_{3}\right)$, promosi $\left(\mathrm{X}_{4}\right)$, dan faktor pelayanan $\left(\mathrm{X}_{5}\right)$ terhadap keputusan pembelian konsumen $(\mathrm{Y})$, artinya sebesar 60,7 persen proporsi variasi variabel Y (keputusan pembelian konsumen) yang dapat dipengaruhi oleh faktor-faktor di atas dan sisanya sebesar 39,3 persen dipengaruhi oleh faktor lain di luar model penelitian ini.

Di bawah ini merupakan hasil analisis regresi ganda (Uji F) yang telah dilakukan:

Tabel 5 ANOVA $^{\mathrm{b}}$

\begin{tabular}{llcccc}
\hline \multicolumn{1}{c}{ Model } & Sum of Squares & df & Mean Square & F & Sig. \\
\hline 1 Regression & 18,068 & 5 & 3,614 & 22,693 &, $000^{\text {a }}$ \\
Residual & 30,892 & 194 &, 159 & & \\
Total & 48,960 & 199 & & & \\
\hline a. Predictors: (Constant), Pelayanan, Lokasi/Tempat, Promosi, Harga, Produk/Barang \\
b. Dependent variable: Keputusan Pembelian
\end{tabular}

Berdasarkan hasil dari tabel di atas, bahwa nilai signifikansi dari faktor variabel produk, lokasi, harga, promosi dan pelayanan adalah 0,000 , berarti kalau dibandingkan dengan $\alpha=0,05$ maka nilai tersebut masih di bawahnya sehingga dapat disimpulkan bahwa secara simultan/bersamaan terdapat pengaruh yang signifikan faktor-faktor tersebut terhadap keputusan pembelian konsumen atau paling sedikit ada satu variabel (X) yang mempengaruhi (Y) dengan tingkat keyakinan 95 persen.

\section{HASIL DAN PEMBAHASAN}

Berdasarkan analisis yang telah dilakukan dalam penelitian bahwa data yang digunakan sudah valid dan reliable karena sudah sesuai dengan standar yang telah ditetapkan. Atas dasar ini, pembahasan dilakukan lebih lanjut mengenai keterkaitan antara hasil analisis, uji hipotesis, dan hubungan penelitian ini dengan penelitian relevan sebelumnya. Hasil analisis koefisien yang diperoleh menjelaskan bahwa variabel faktor produk, lokasi, harga, promosi, dan pelayanan memiliki pengaruh yang kuat dan positif terhadap variabel keputusan pembelian konsumen, yaitu sebesar 60,7 persen dan sisanya 39,3 persen dapat dipengaruhi oleh faktor lain diluar model penelitian ini. Selain itu, hasil uji $\mathrm{t}$ menunjukkan bahwa semua faktor memiliki pengaruh yang signifikan pada variabel keputusan pembelian konsumen kecuali faktor lokasi yang tidak berpengaruh terhadap keputusan pembelian konsumen di AlfaMart. 
Dari hasil pengujian hipotesis yang telah dilakukan, menunjukkan bahwa hipotesis yang diajukan dapat diterima karena dari lima variabel independen yang ada pada penelitian ini telah terbukti secara impiris memiliki pengaruh yang signifikan terhadap variabel dependennya (keputusan pembelian konsumen), kecuali variabel lokasi yang tidak terbukti berpengaruh karena nilai sig. 0,478 $>0,05$. Sementara faktor yang paling dominan berpengaruh dalam keputusan pembelian konsumen adalah faktor pelayanan, karena nilai sig. $0,000<0,05$.

Dibandingkan dengan penelitian sebelumnya yang dilakukan oleh Nanang (2005) dan Hartanti (2004), penelitian mereka mendukung hasil penelitian sebelumnya yaitu berpengaruh positif signifikan, namun faktor yang dominan berpengaruh pada penelitian ini adalah faktor pelayanan, sedangkan penelitian sebelumnya adalah faktor produk. Hasil penelitian ini adalah faktor lokasi tidak berpengaruh, karena lokasi dianggap oleh konsumen bukan sebuah kendala karena komsumen membeli kebutuhan pokok.

\section{SIMPULAN}

Berdasarkan hasil penelitian dan pembahasan yang telah dilakukan maka dapat disimpulan bahwa (1) Terdapat pengaruh yang signifikan dalam faktor produk terhadap keputusan pembelian konsumen. (2) Tidak terdapat pengaruh faktor lokasi terhadap keputusan pembelian konsumen. (3) Terdapat pengaruh yang signifikan dalam faktor harga terhadap keputusan pembelian konsumen. (4) Terdapat pengaruh yang signifikan dalam faktor promosi terhadap keputusan pembelian konsumen. (5) Terdapat pengaruh yang signifikan dalam faktor pelayanan terhadap keputusan pembelian konsumen (6) Hasil pengujian secara simultan (Uji F) menunjukkan terdapat pengaruh yang signifikan dalam faktor produk, lokasi, harga, promosi dan pelayanan terhadap keputusan pembelian.

Berdasarkan hasil penelitian dan simpulan yang ada, faktor-faktor yang mempengaruhi keputusan pembelian konsumen adalah faktor pelayanan. Faktor pelayanan sebaiknya dipertahankan dan/atau ditingkatkan. Untuk penelitian berikutnya, jumlah variabel dan responden sebaiknya ditambah dan analisis lain digunakan sehingga keakurasian penelitian dapat ditingkatkan.

\section{DAFTAR PUSTAKA}

Arikunto, S. (2002). Prosedur Penelitian. Jakarta: PT. Rineka Cipta.

Djarwanto, P. S., Sudibyo, P. (1996). Statistik Induktif. Yogyakarta: BPFE.

Engel, J. F., Blackwell, R. D., Miniard, P. W. (1994). Perilaku Konsumen. Jakarta: Binarupa Aksara.

Hartanti, T. (2004). Analisis Faktor-faktor Yang Mempengaruhi Keputusan Pembelian Konsumen Pada Toko Thalita Tawang Sukoharjo. Surakarta: UNS.

Kotler, P. (2002). Manajemen Pemasaran. Edisi Milenium. Jakarta: Prenhalindo.

Loudon, D. L., Bitta, A. J. D. (1993). Consumer Behavior: Concepts and Applications, Volume 1. New York: McGraw-Hill.

Ma'ruf, H. (2005). Pemasaran Ritel. Jakarta: PT Gramedia Pustaka Utama

Nanang, P. S. (2005). Analisis Faktor-faktor Yang Mempengaruhi Keputusan Konsumen Dalam Melakukan Pembelian Pada Toko Sport Station Malioboro Mall Yogyakarta. Surakarta: UNS. 
Peter, J. P., Olson, J. C., Grunert, K. G. (1999). Consumer Behaviour and Marketing Strategy. New York: McGraw-Hill

Singarimbun, M., Effendi, S. (2005). Metode Penelitian Survei. Jakarta: Elex Media Komputindo.

Solomon, R. M. (2002). Consumer Behavior. New York: Upper Saddle River.

Swastha, B. D. (1996). Asas-asas Marketing. Edisi III. Yogyakarta: Liberty

Swastha, B. D., Handoko, T. H. (1997). Manajemen Pemasaran Analisis Perilaku Konsumen. Yogyakarta: Liberty.

Stanton, W. J., Lamarto, Y. (1999). Prinsip Pemasaran. Edisi VII. Jakarta: Erlangga.

Sugiyono, P. R. (1997). Metode Penelitian Bisnis. Bandung: Alfabeta. 